Open Access

\title{
Complete genome sequence of the molybdenum-resistant bacterium Bacillus subtilis strain LM 4-2
}

Xiao-Yan You ${ }^{1}$, Hui Wang ${ }^{1}$, Guang-Yue Ren ${ }^{1}$, Jing-Jing Li ${ }^{1}$, Xu Duan ${ }^{1}$, Hua-Jun Zheng ${ }^{2}$ and Zheng-Qiang Jiang ${ }^{1,3^{*}}$

\begin{abstract}
Bacillus subtilis LM 4-2, a Gram-positive bacterium was isolated from a molybdenum mine in Luoyang city. Due to its strong resistance to molybdate and potential utilization in bioremediation of molybdate-polluted area, we describe the features of this organism, as well as its complete genome sequence and annotation. The genome was composed of a circular 4,069,266 bp chromosome with average GC content of $43.83 \%$, which included 4149 predicted ORFs and 116 RNA genes. Additionally, 687 transporter-coding and 116 redox protein-coding genes were identified in the strain LM 4-2 genome.
\end{abstract}

Keywords: Gram-positive, Molybdate, Bioremediation, Molybdenum-resistance, Bacillus subtilis LM 4-2

\section{Introduction}

Bacillus subtilis LM 4-2 was a molybdenum-resistant strain isolated from a molybdenum mine. It has been reported that many microbes can resist the toxicity of molybdate ion though reduction of molybdate $\left(\mathrm{Mo}^{6+}\right)$ to Mo-blue. Molybdenum-reducing microorganisms came from a variety of genera and included the following species, Klebsiella spp. [1, 2], Acidithiobacillus ferrooxidans [3], Enterobacter cloacae [4], Serratia marcescens [5, 6], Acinetobacter calcoaceticus [7], Pseudomonas spp. [8], and Escherichia coli K12 [9]. The capability of molybdatereduction presents potential possibility of molybdenum bioremediationin many polluted areas [10]. Strain LM 4-2 showed stronger resistance to molybdate (up to $850 \mathrm{mM}$ $\mathrm{Na}_{2} \mathrm{MoO}_{4}$ ) than many other reported molybdenumresistant bacteria $[11,12]$. However, no information related to the molecular mechanism of molybdenum-resistance has been identified, also in genus Bacillus. Thus, strain LM 4-2 might be a perfect subject for us to unveil the mechanism and evaluate its possibility utilization in bioremediation. Here we present the complete genome

\footnotetext{
*Correspondence: zhqjiang@cau.edu.cn

${ }^{1}$ College of Food and Bioengineering, Henan University of Science and Technology, Luoyang, P. R. China

${ }^{3}$ College of Food Science and Nutritional Engineering, China Agricultural

University, Beijing, P. R. China

Full list of author information is available at the end of the article
}

sequence and detailed genomic features of $B$. subtilis LM 4-2.

\section{Organism information Classification and features}

Bacillus subtilis LM 4-2 (CGMCC 1.15213) is a Grampositive, spore-forming, rod-shaped Bacillus (0.3-0.5 $\mu \mathrm{m}$ wide and 3.0-4.0 $\mu \mathrm{m}$ long) with an optimum $\mathrm{pH} 6.0$ and optimum temperature of $30{ }^{\circ} \mathrm{C}$ (Table 1, Fig. 1). Colonies are milky white and matte with a wrinkled surface when growth on R2A agar medium. Strictly aerobic and catalase formed. Carbon substrates utilized for growth by strain LM 4-2 included D-glucose, maltose, lactose and sucrose. Strain LM 4-2 is closely related to Bacillus subtilis species based on the BLAST results of 16S rRNA gene [27]. The identity of $16 \mathrm{~S}$ rRNA gene sequence between strain LM 4-2 and type strain B. subtilis DSM $10^{\mathrm{T}}$ is $100 \%$. A phylogenetic tree was constructed using the neighbor-Joining method under the default settings for complete sequence of $16 \mathrm{~S}$ rRNA gene derived from genome of strain LM 4-2, along with the sequences of representative members of genus Bacillus [28-34]. The phylogenetic tree was assessed by boot-strapped for 1000 times, which is shown in Fig. 2. Average nucleotide 
Table 1 Classification and general features of Bacillus subtilis LM 4-2 according to the MIGS recommendations [13]

\begin{tabular}{|c|c|c|c|}
\hline MIGS ID & Property & Term & Evidence code $^{\mathrm{a}}$ \\
\hline & Classification & Domain Bacteria & TAS [14] \\
\hline & & Phylum Firmicutes & TAS [15-17] \\
\hline & & Class Bacilli & $\operatorname{TAS}[18,19]$ \\
\hline & & Order Bacillales & $\operatorname{TAS}[20,21]$ \\
\hline & & Family Bacillaceae & TAS $[20,22]$ \\
\hline & & Genus Bacillus & $\operatorname{TAS}[20,23,24]$ \\
\hline & & Species Bacillus subtilis & TAS [25] \\
\hline & Gram stain & Positive & IDA \\
\hline & Cell shape & Rod-shaped & IDA \\
\hline & Motility & Motile & IDA \\
\hline & Sporulation & Spore-forming & NAS \\
\hline & Temperature range & $4-45^{\circ} \mathrm{C}$ & IDA \\
\hline & Optimum temperature & $30^{\circ} \mathrm{C}$ & IDA \\
\hline & pH range; Optimum & $4-9 ; 6.0$ & IDA \\
\hline & Carbon source & organic carbon source & IDA \\
\hline MIGS-6 & Habitat & soil & IDA \\
\hline MIGS-6.3 & Salinity & salt tolerant & NAS \\
\hline MIGS-22 & Oxygen requirement & aerobic & IDA \\
\hline MIGS-15 & Biotic relationship & free-living & NAS \\
\hline MIGS-14 & Pathogenicity & non-pathogen & NAS \\
\hline MIGS-4 & Geographic location & Luoyang/Henan/China & IDA \\
\hline MIGS-5 & Sample collection & 2012 & IDA \\
\hline MIGS-4.1 & Latitude & $33^{\circ} 55^{\prime} 3.21^{\prime \prime} \mathrm{N}$ & \\
\hline MIGS-4.2 & Longitude & $111^{\circ} 31^{\prime} 0.42^{\prime \prime} \mathrm{E}$ & \\
\hline MIGS-4.4 & Altitude & 1164.78 & \\
\hline
\end{tabular}

Evidence codes - IDA Inferred from Direct Assay, TAS Traceable Author Statement (i.e., a direct report exists in the literature), NAS Non-traceable Author Statement (i.e., not directly observed for the living, isolated sample, but based on a generally accepted property for the species, or anecdotal evidence). These evidence codes are from the Gene Ontology project [26]

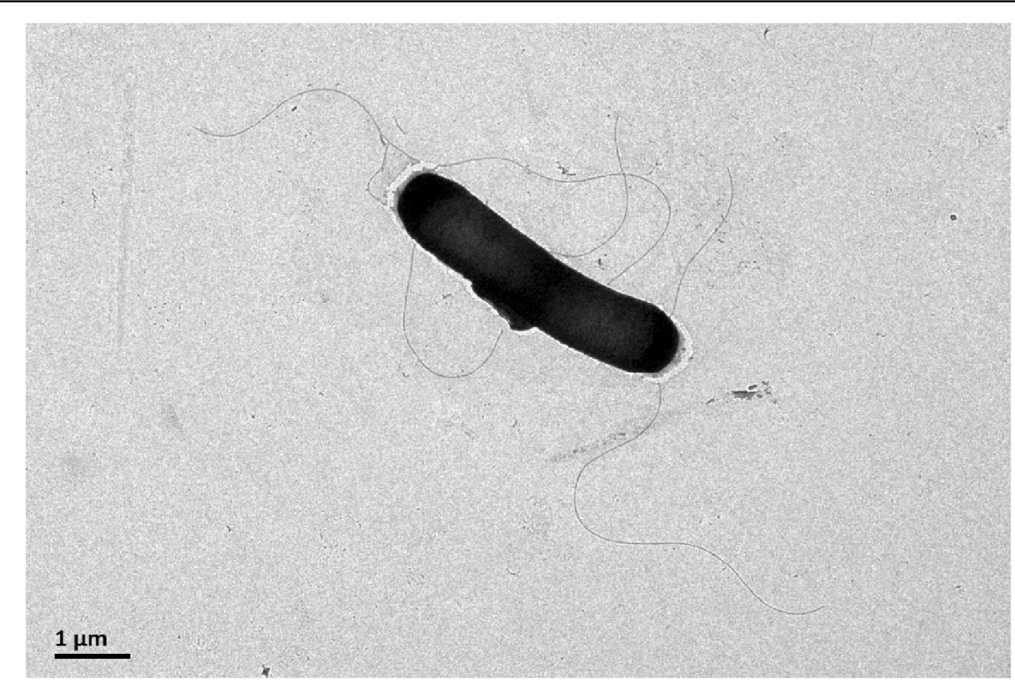

Fig. 1 Transmission electron microscopy of strain LM 4-2. Scale bar corresponds to $1.0 \mu \mathrm{m}$ 


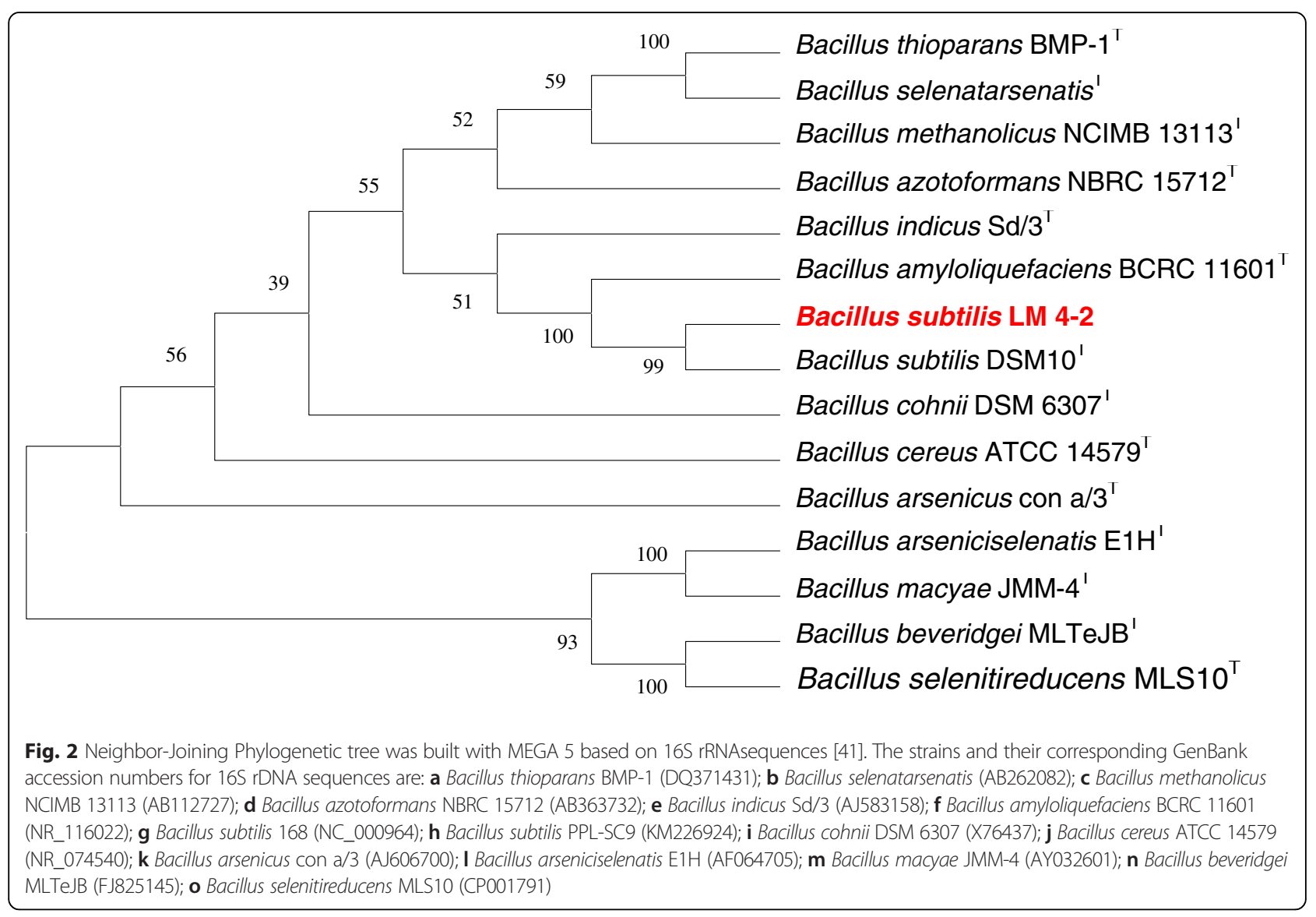

identity (ANI), average amino acid identity (AAI) and in silico Genome-to-Genome Hybridization value (GGDH) were calculated between the genomes of strain LM 4-2 and other $30 \mathrm{~B}$. subtilis species that have been completed sequenced [35-40]. Results show that strain LM 4-2 shares high ANI ( $>95 \%$, 23 of total 30), AAI ( $>95 \%, 23$ of total 30$)$ and GGDH value ( $>70 \%, 24$ of total 30$)$ with most of the complete sequenced B. subtilis species, and highest ANI (99.00\%), AAI (99.13\%) and GGDH value $(92.20 \% \pm 1.85)$ with $B$. subtilis strain TO-A JPC (Additional file 1: Table S1).

\section{Genome sequencing information Genome project history}

Bacillus subtilis LM 4-2 was selected for sequencing due to its strong resistance to molybdate and potential utilization in bioremediation of molybdate-polluted areas. The genome sequence was deposited in GenBank under accession number CP011101 and the genome project was deposited in the Genomes on Line Database [42] under Gp0112736. Genome sequencing and annotation were performed by Chinese National Human Genome Center at Shanghai. A summary of the project was given in Table 2 .
Growth conditions and genomic DNA preparation Bacillus subtilis LM 4-2 was inoculated in $200 \mathrm{~mL}$ R2A medium and cultivated for $8 \mathrm{~h}$ at $30{ }^{\circ} \mathrm{C}$ in a shaker with speed of $200 \mathrm{rpm} .1 .2 \mathrm{~g}$ of harvested cells was suspended in $5 \mathrm{~mL}$ TE (pH8.0) with $10 \mathrm{mg} / \mathrm{mL}$ lysozymeat $30{ }^{\circ} \mathrm{C}$

Table 2 Genome sequencing project information

\begin{tabular}{lll}
\hline MIGS ID & Property & Term \\
\hline MIGS 31 & Finishing quality & Complete \\
MIGS-28 & Libraries used & $\begin{array}{l}\text { Two libraries, 20 Kb PacBio } \\
\text { library, 2 } 150 \text { bpllumina library }\end{array}$ \\
MIGS 29 & Sequencing platforms & PacBio RS II, Illumina Hi-Seq \\
MIGS 31.2 & Fold coverage & 213-and 409-fold \\
MIGS 30 & Assemblers & HGAP, bowtie2 \\
MIGS 32 & Gene calling method & Glimmer 3.02 and GeneMark \\
& Locus Tag & BsLM \\
& Genbank ID & CP011101 \\
& GenBank Date of Release & April 23, 2015 \\
& GOLD ID & Gp0112736 \\
& BIOPROJECT & PRJNA277611 \\
MIGS 13 & Source Material Identifier & CGMCC 1.15213 \\
& Project relevance & Environmental, Bioremediation \\
\hline
\end{tabular}


Table 3 Genome statistics

\begin{tabular}{lll}
\hline Attribute & Value & \% of Total \\
\hline Genome size (bp) & $4,069,266$ & 100.00 \\
DNA coding (bp) & $3,596,010$ & 88.37 \\
DNA G + C (bp) & $1,811,637$ & 44.52 \\
Total genes & 4265 & 100.00 \\
Protein coding genes & 4149 & 97.28 \\
RNA genes & 116 & 2.72 \\
rRNA operons & 10 & 0.23 \\
Genes with function prediction & 2742 & 64.29 \\
Genes assigned to COGs & 3111 & 72.94 \\
Genes with Pfam domains & 3656 & 85.72 \\
Genes with signal peptides & 541 & 12.68 \\
Genes with transmembrane helices & 778 & 18.24 \\
CRISPR repeats & 0 & 0
\end{tabular}

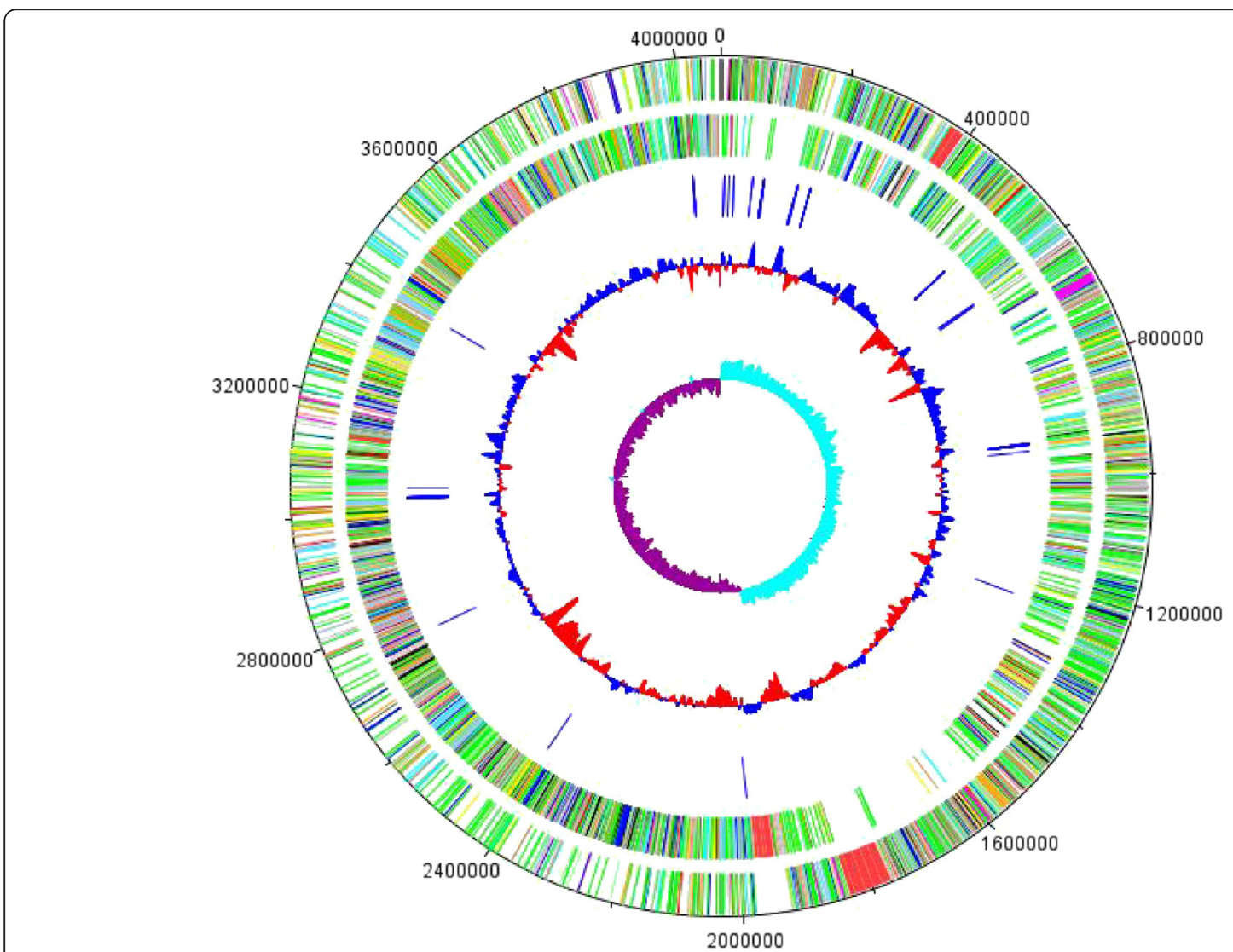

Fig. 3 Graphic representation of circular map of the chromosome of strain LM 4-2.The map was generated with the DNAPlotter [54]. From outside to the center: the first two outer circles represent the positions of genes in the chromosome (Circle 1: plus strand, Circle 2: minus strand). Circle 3 represents tRNA genes (blue), Circle 4 represents G + C content, and Circle 5 represents GC skew for $4 \mathrm{~h}$. After centrifugation (12,000 rpm) for $10 \mathrm{~min}$, genomic DNA was extracted by phenol-chloroform methods as described previously [43]. DNA was dissolved in $2 \mathrm{~mL}$ sterilized deionized water with a final concentration of $12.67 \mu \mathrm{g} / \mu \mathrm{L}$ and 2.04 of OD260/OD280 ratio determined by NanoDrop 2000 spectrophotometer (Thermo Scientific, USA). The genomic DNA was stored in $-20^{\circ} \mathrm{C}$ freezer.

\section{Genome sequencing and assembly}

The genome of Bacillus subtilis LM 4-2 was sequenced by a dual sequencing approach that using a combination of PacBio RS II and Genome Analyzer IIx sequence platforms. Approximately 121,583 PacBio and 1637 million Illumina reads were generated from PacBio platform and the Illumina platform $(2 \times 150$ bp paired-end sequencing $)$ with average sequence coverage of 213-and 409-fold.Sequence reads from the PacBio RS II were assembled by using hierarchical genome-assembly process assembler and finally only one self-cycled supper contig was generated. The Illumina reads were quality trimmed with the CLC Genomics Workbench and then utilized for error correction of the PacBio reads by using bowtie2 (version 2.1.0) software [44]. 


\section{Genome annotation}

The Glimmer 3.02 and GeneMark programs were used to predict the positions of open reading frames [45, 46]. Protein function was predicted by the following methods: 1) homology searches in the GenBank and UniProt protein database [47]; 2) function assignment searches in CDD database [48]; and 3) domain or motif searches in the Pfam databases [49]. The KEGG database was used to reconstruct metabolic pathways [50]. Ribosomal RNAs and Transfer RNAs were predicted by using RNAmmer and tRNAscan-SE programs [51, 52]. Transporters were predicted by searching the TCDB database using BLASTP program $[27,53]$ with expectation value lower than $1 \mathrm{e}-05$.

\section{Genome properties}

The complete strain LM 4-2 genome was composed of a circular 4,069,266 bp chromosome with an overall $43.83 \% \mathrm{G}+\mathrm{C}$ content. Four thousand one hundred forty-nine ORFs, 10 sets of rRNA operons, and 84 tRNAs were predicted in the LM 4-2 genome (Table 3 and Fig. 3). Two thousand seven hundred forty-two of total 4149 predicted ORFs could be functional assignment, 1415 were annotated as hypothetical proteins. When analyzed for biological roles according to COG categories, amino acid transport and metabolism proteins accounted for the largest percent $(7.18 \%)$ of all functionally assigned proteins, followed by carbohydrate transport and metabolism proteins (6.89\%), and Transcription proteins $(6.43 \%)$. There are 687 transportercoding and 116 redox protein-coding genes were identified in the LM 4-2 genome. The distribution of genes into COGs functional categories is presented in Table 4.

\section{Conclusions}

Molybdenum pollution has been reported in water and soils all around the world [55]. Some Mo-resistance bacteria can be used to immobilize soluble molybdenum toinsoluble formsalong with reducing the toxicity. In this study we presented the complete genome sequence of Bacillus subtilis LM 4-2, which was isolated from a molybdenum mine in Luoyang city. Due to its strong resistance to molybdate and potential utilization in bioremediation of molybdate-polluted area, we sequence the genome and try to identify the possible molecular mechanism of molybdenum-resistance. Genomic analysis of strain LM 4-2 revealed 687 transporter-coding and 116 redox protein-coding genes were separated in the genome. Three genome islands were identified in the strain LM 4-2 genome, covering $2.71 \%$ of the whole genome. Three gene clusters were involved in the non-ribosomal synthesis of lipopeptides, such as surfactin, fengycin, and dipeptide bacilysin. Additionally, one gene clusters for subtilosin A synthesis and one gene clusters for polyketide synthesis. No CRISPRs were identified in the strain LM 4-2 genome.
Table 4 Number of genes associated with general COG functional categories ${ }^{a}$

\begin{tabular}{|c|c|c|c|}
\hline Code & Value & $\%$ age & Description \\
\hline J & 149 & 3.59 & Translation, ribosomal structure and biogenesis \\
\hline A & 0 & 0.00 & RNA processing and modification \\
\hline K & 267 & 6.44 & Transcription \\
\hline L & 114 & 2.75 & Replication, recombination and repair \\
\hline B & 1 & 0.02 & Chromatin structure and dynamics \\
\hline D & 36 & 0.87 & $\begin{array}{l}\text { Cell cycle control, Cell division, chromosome } \\
\text { partitioning }\end{array}$ \\
\hline V & 54 & 1.30 & Defense mechanisms \\
\hline $\mathrm{T}$ & 127 & 3.06 & Signal transduction mechanisms \\
\hline M & 191 & 4.60 & Cell wall/membrane biogenesis \\
\hline N & 60 & 1.45 & Cell motility \\
\hline$U$ & 25 & 0.60 & Intracellular trafficking and secretion \\
\hline O & 101 & 2.43 & $\begin{array}{l}\text { Posttranslational modification, protein turnover, } \\
\text { chaperones }\end{array}$ \\
\hline C & 166 & 4.00 & Energy production and conversion \\
\hline G & 286 & 6.89 & Carbohydrate transport and metabolism \\
\hline E & 298 & 7.18 & Amino acid transport and metabolism \\
\hline $\mathrm{F}$ & 82 & 1.98 & Nucleotide transport and metabolism \\
\hline $\mathrm{H}$ & 114 & 2.75 & Coenzyme transport and metabolism \\
\hline । & 89 & 2.14 & Lipid transport and metabolism \\
\hline$P$ & 168 & 4.05 & Inorganic ion transport and metabolism \\
\hline Q & 72 & 1.74 & $\begin{array}{l}\text { Secondary metabolites biosynthesis, transport } \\
\text { and catabolism }\end{array}$ \\
\hline $\mathrm{R}$ & 364 & 8.77 & General function prediction only \\
\hline S & 347 & 8.36 & Function unknown \\
\hline- & 1039 & 25.04 & Not in COGs \\
\hline
\end{tabular}

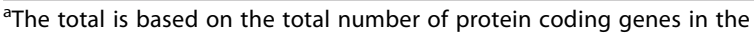
annotated genome

The complete genome sequence of strain LM 4-2 will facilitate functional genomics to elucidate the molecular mechanisms that underlie molybdenumresistance and it may facilitate the bioremediation of molybdenum-contaminated areas.

\section{Additional file}

Additional file 1: Table S1. The results of ANI, AAI and GGDH value between genomes of strain LM 4-2 and other 30 complete sequenced B. subtilis species. (DOC $58 \mathrm{~kb}$ )

\section{Competing interests}

The authors declare that they have no competing interests.

\section{Authors' contributions}

$X-Y Y$ and HW participated in the design of the study, carried out the molecular genetic studies and drafted the manuscript. G-YR and XD performed the laboratory experiments. J-JL prepared the genomic DNA. H-JZ performed the bioinformatics analysis. Z-QJ conceived of the study and helped to draft the manuscript. All authors read and approved the final manuscript. 


\section{Acknowledgements}

This work was financially supported by the National Natural Science Foundation of China $(31200035,41201224)$ and by the Research Fund for the Doctoral Program of Henan University of Science and Technology under Grant (09001608). Transmission electron microscopy was provided by instrument center of Institute of Microbiology, Chinese Academy of Sciences.

\section{Author details}

${ }^{1}$ College of Food and Bioengineering, Henan University of Science and Technology, Luoyang, P. R. China. ${ }^{2}$ Chinese National Human Genome Center at Shanghai, Shanghai (CHGC) 201203, P. R. China. ${ }^{3}$ College of Food Science and Nutritional Engineering, China Agricultural University, Beijing, P. R. China.

Received: 27 April 2015 Accepted: 3 December 2015

\section{Published online: 10 December 2015}

\section{References}

1. Lim HK, Syed MA, Shukor MY. Reduction of molybdate to molybdenum blue by Klebsiella sp. strain hkeem. J Basic Microbiol. 2012;52(3):296-305.

2. Halmi MI, Zuhainis SW, Yusof MT, Shaharuddin NA, Helmi W, Shukor Y, et al. Hexavalent molybdenum reduction to mo-blue by a sodium-dodecyl-sulfatedegrading Klebsiellaoxytoca strain DRY14. Biomed Res Int. 2013;2013:384541.

3. Sugio T, Tsujita Y, Katagiri T, Inagaki K, Tano T. Reduction of $\mathrm{Mo}^{6+}$ with elemental sulfur by Thiobacillus ferrooxidans. J Bacteriol. 1988;170(12):5956-9.

4. Shukor A, Yunus M, Lee CH, Omar I, Karim MIA, Syed MA, et al. Isolation and characterization of a molybdenum reducing enzyme in Enterobacter cloacae strain 48. Asia Pac J Mol Biol Biotechnol. 2003;11(2):261-72.

5. Shukor MY, Halmi MIE, Rahman MFA, Shamaan NA, Syed MA. Molybdenum reduction to molybdenum blue in Serratia sp. strain DRY5 is catalyzed by a novel molybdenum-reducing enzyme. Biomed Res Int. 2014;2014:853084 doi:10.1155/2014/853084.

6. Shukor MY, Rahman MF, Shamaan NA, Syed MA. Reduction of molybdate to molybdenum blue by Enterobacter sp. strain Dr.Y13. J Basic Microbiol. 2009; 49 Suppl 1:S43-54.

7. Shukor MY, Rahman MF, Suhaili Z, Shamaan NA, Syed MA. Hexavalent molybdenum reduction to Mo-blue by Acinetobacter calcoaceticus. Folia Microbiol (Praha). 2010;55(2):137-43.

8. Shukor MY, Ahmad SA, Nadzir MMM, Abdullah MP, Shamaan NA, Syed MA Molybdate reduction by Pseudomonas sp. strain DRY2. J Appl Microbiol. 2010;108(6):2050-8. doi:10.1111/j.1365-2672.2009.04604.x.

9. Campbell AM, del Campillo-Campbell A, Villaret DB. Molybdate reduction by Escherichia coli K-12 and its chi mutants. Proc Natl Acad Sci U S A. 1985; 82(1):227-31.

10. Neunhäuserer $\mathrm{C}$, Berreck $\mathrm{M}$, Insam $\mathrm{H}$. Remediation of soils contaminated with molybdenum using soil amendments and phytoremediation. J Water Air Soil Poll. 2001;128:85-96.

11. Nasernejad B, Kaghazchi T, Edrisi M, Sohrabi M. Bioleaching of molybdenum from low-grade copper ore. Process Biochem. 1999;35:437-40.

12. Olson GJ, Clark TR. Bioleaching of molybdenite. Hydrometallurgy. 2008;93:10-5.

13. Field D, Garrity G, Gray T, Morrison N, Selengut J, Sterk P, et al. The minimum information about a genome sequence (MIGS) specification. Nat Biotechnol. 2008;26:541-7.

14. Woese CR, Kandler O, Wheelis ML. Towards a natural system of organisms: proposal for the domains Archaea, Bacteria, and Eucarya. Proc Natl Acad Sci U S A. 1990;87(12):4576-9.

15. Gibbons NE, Murray RGE. Proposals concerning the higher taxa of bacteria. Int J Syst Bacteriol. 1978;28:1-6.

16. Garrity GM, Holt JG. The road map to the manual. In: Boone DR, Castenholz RW, Garrity GM, editors. Bergey's manual of systematic bacteriology.Volume 1. 2nd ed. New York: Springer; 2001. p. 119-69.

17. Murray RGE. The higher taxa, or, a place for everything...? In: Holt JG, editor Bergey's manual of systematic bacteriology. Volume 1. 1st ed. Baltimore: The Williams and Wilkins Co; 1984. p. 31-4

18. List no.132. List of new names and new combinations previously effectively, but not validly, published. Int J Syst Evol Microbiol. 2010;60:469-72.

19. Ludwig W, Schleifer KH, Whitman WB. Bacilli class.nov. In: Vos P, Garrity G, Jones D, Krieg NR, Ludwig W, Rainey FA, Schleifer KH, Whitman WB, editors. Bergey's manual of systematic bacteriology. Volume 3. 2nd ed. New York: Springer-Verlag; 2009. p. 19-20.

20. Skerman VBD, McGowan V, Sneath PHA. Approved lists of bacterial names. Int J Syst Bacteriol. 1980;30:225-420
21. Prévot AR. In: Hauderoy P, Ehringer G, Guillot G, Magrou J, Prévot AR, Rosset $D$, Urbain A, editors. Dictionnaire des bactéries pathogènes. 2nd ed. Paris: MassonetCie; 1953. p. 1-692.

22. Fischer A. Untersuchungen über bakterien. Jahrbuch für Wissenschaftliche Botanik. 1895;27:1-163.

23. Cohn F. Untersuchungen über bakterien. Beitrage zur Biologie der Pflanzen Heft 2. 1872;1:127-224.

24. Gibson T, Gordon RE. Genus I. Bacillus Cohn 1872. In: Buchanan RE, Gibbons, editors. Bergey's manual of determinative bacteriology. 8th ed. Baltimore: Williams and Wilkins Co; 1974. p. 529-50.

25. Nakamura LK, Roberts MS, Cohan FM. Relationship of Bacillus subtilis clades associated with strains 168 and W23: a proposal for Bacillus subtilissubtilis subsp. nov. and Bacillussubtilis spizizenii subsp. Nov. Int J Syst Bacteriol. 1999:49 Pt 3:1211-5.

26. Ashburner M, Ball CA, Blake JA, Botstein D, Butler H, Cherry JM, et al. Gene ontology: tool for the unification of biology. Nat Genet. 2000;25:25-9.

27. Altschul SF, Gish W, Miller W, Myers EW, Lipman DJ. Basic local alignment search tool. J Mol Biol. 1990;215(3):403-10.

28. Skerman VBD, McGowan V, Sneath PHA. Approved lists of bacterial names. Int J Syst Bacteriol. 1980;30:225-420.

29. Borriss R, Chen XH, Rueckert C, Blom J, Becker A, Baumgarth B, et al. Relationship of Bacillus amyloliquefaciens clades associated with strains DSM $7^{\top}$ and FZB42 ${ }^{\top}$ : a proposal for Bacillus amyloliquefaciens subsp. amyloliquefaciens subsp. nov. and Bacillus amyloliquefaciens subsp. plantarum subsp. nov. based on complete genome sequence comparisons. Int J Syst Evol Microbiol. 2011;61(8):1786-801.

30. Goto K, Fujita R, Kato Y, Asahara M, Yokota A. Reclassification of Brevibacillus brevis strains NCIMB 13288 and DSM 6472 (= NRRL NRS-887) as Aneurinibacillus danicus sp. nov. and Brevibacillus limnophilus sp. nov. Int I Syst Evol Microbiol. 2004:54(2):419-27.

31. Ehrenberg CG. Dritter Beitrag zur Erkenntniss grosser Organisation in der Richtung des kleinsten Raumes. Physikalische Abhandlungen der Koeniglichen Akademie der Wissenschaften zu Berlin aus den Jahren. 1833;1835:143-336.

32. Pichinoty F, De Barjac H, Mandel M, Asselineau J. Description of Bacillus azotoformans sp. nov. Int J Syst Bacteriol. 1983;33(3):660-2.

33. Santini JM, Streimann IC, Vanden Hoven RN. Bacillus macyae sp. nov., an arsenate-respiring bacterium isolated from an Australian gold mine. Int J Syst Evol Microbiol. 2004;54(6):2241-4.

34. Spanka R, Fritze D. Bacillus cohnii sp. nov., a new, obligately alkaliphilic, ovalspore-forming Bacillus species with ornithine and aspartic acid instead of diaminopimelic acid in the cell wall. Int J Syst Evol Microbiol. 1993;43(1):150-6.

35. Rodriguez-R LM, Konstantinidis KT. By passing cultivation to identify bacterial species. Microbe. 2014;9(3):111-8.

36. Kim M, Oh HS, Park SC, Chun J. Towards a taxonomic coherence between average nucleotide identity and 16S rRNA gene sequence similarity for species demarcation of prokaryotes. Int J Syst Evol Microbiol. 2014;64(2):346-51.

37. Guo Q, Li S, Lu X, Zhang X, Wang P, Ma P. Complete genome sequence of Bacillus subtilis BAB-1, a biocontrol agent for suppression of tomato gray mold. Genome announcements. 2014;2(4):e00744-14.

38. Motozaki S, Tsunoda T, Aoki R, Okumura S, Kondo Y, Muramatsu N, et al. Method for preparation of inosine. US Patent 3,111,459 dated Nov 191963.

39. Jansen EF, Hirschmann DJ. Subtilin-an antibacterial product of Bacillus subtilis. Culturing conditions and properties. Arch Biochem Biophys. 1944;4: 297-309.

40. Masahiko Y, Makoto K, Teluji H, Ikuo N, Akira I, Yuichi T, et al. Method for the production of guanosine and 5'-guanylic acid. US Patent 3,607,649 dated Sep 211971.

41. Tamura K, Peterson D, Peterson N, Stecher G, Nei M, Kumar S. MEGA5: Molecular Evolutionary Genetics Analysis using maximum likelihood, evolutionary distance, and maximum parsimony methods. Mol Biol Evol. 2011;28(10):2731-9.

42. Reddy TB, Thomas AD, Stamatis D, Bertsch J, Isbandi M, Jansson J, et al. The Genomes OnLine Database (GOLD) v. 5: a metadata management system based on a four level (meta) genome project classification. Nucleic Acids Res. 2015:43(Database issue):D1099-106.

43. You XY, Guo X, Zheng HJ, Zhang MJ, Liu LJ, Zhu YQ, et al. Unraveling the Acidithiobacillus caldus complete genome and its central metabolisms for carbon assimilation. J Genet Genomics. 2011;38(6):243-52.

44. LangmeadB SSL. Fast gapped-read alignment with Bowtie 2. Nat Methods. 2012;9(4):357-9.

45. Delcher AL, Bratke KA, Powers EC, Salzberg SL. Identifying bacterial genes and endosymbiont DNA with Glimmer. Bioinformatics. 2007;23(6):673-9. 
46. Borodovsky M, Mclninch J. GeneMark: parallel gene recognition for both DNA strands. Computers \& Chemistry. 1993;17(19):123-33.

47. UniProt Consortium. UniProt: a hub for protein information. Nucleic Acids Res. 2015:43(Database issue):D204-D212

48. Marchler-Bauer A, Derbyshire MK, Gonzales NR, Lu S, Chitsaz F, Geer LY, et al. CDD: NCBI's conserved domain database. Nucleic Acids Res. 2015;43(Database issue):D222-D226

49. Finn RD, Bateman A, Clements J, Coggill P, Eberhardt RY, Eddy SR, et al. Pfam: the protein families database. Nucleic Acids Res. 2014;42(Database issue):D222-D230.

50. Kanehisa M, Sato Y, Kawashima M, Furumichi M, Tanabe M. KEGG as a reference resource for gene and protein annotation. Nucleic Acids Res. 2015. gkv1070.

51. Lagesen K, Hallin P, Rødland EA, Stærfeldt HH, Rognes T, Ussery DW. RNAmmer: consistent and rapid annotation of ribosomal RNA genes. Nucleic Acids Res. 2007;35(9):3100-8.

52. Lowe TM, Eddy SR. tRNAscan-SE: a program for improved detection of transfer RNA genes in genomic sequence. Nucleic Acids Res. 1997;25:955-64.

53. Saier MH, Tran CV, Barabote RD. TCDB: the Transporter Classification Database for membrane transport protein analyses and information. Nucleic Acids Res. 2006;34 suppl1:D181-6.

54. Carver T, Thomson N, Bleasby A, Berriman M, Parkhill J. DNAPlotter: circular and linear interactive genome visualization. Bioinformatics. 2009;25(1):119-20.

55. Ahmad SA, Shukor MY, Shamaan NA, Mac Cormack WP, Syed MA Molybdate reduction to molybdenum blue by an Antarctic bacterium. BioMed Res Int. 2013;2013:871941. doi:10.1155/2013/871941.

\section{Submit your next manuscript to BioMed Central} and we will help you at every step:

- We accept pre-submission inquiries

- Our selector tool helps you to find the most relevant journal

- We provide round the clock customer support

- Convenient online submission

- Thorough peer review

- Inclusion in PubMed and all major indexing services

- Maximum visibility for your research 